\title{
Hydrography of the Artabro Gulf in summer: western coastal limit of Cantabrian seawater and wind-induced upwelling at Prior Cape
}

\author{
Ricardo PREGO ${ }^{a * k}$, Manuel VARELA $^{\mathrm{b}}$ \\ ${ }^{\text {a }}$ Instituto de Investigaciones Marinas, CSIC, 36208 Vigo, Spain \\ (E-mail: prego@iim.csic.es) \\ ${ }^{b}$ Centro Oceanográfico, IEO, 15001 La Coruña, Spain \\ (E-mail: manuel.varela@co.ieo.es)
}

(Revised 29/12/97, accepted 06/01/98)

\begin{abstract}
The Artabro Gulf (1500 $\mathrm{km}^{2}$ north-west of the Iberian Peninsula) has been studied based on data obtained in August 1993, under typical summer metcorological conditions (COPLA 893 cruisc). This is the first study on the summer hydrography of the Artabro Gulf. During this season, the hydrography of this area is quite complex and must be understood in terms of three factors: 1) upwelling, 2) two different eastern North Atlantic Central Water (EN $\Lambda \mathrm{CW}$ ) water masses and 3) rias water exchange. A local wind-induced upwelling of $\mathrm{ENACW}_{\mathrm{p}}$ (subpolar) occurs off Prior Cape. The plume is located off the gulf coastline, but inside the continental shelf. The frontal zone, rich in nutrients and chlorophyll, is parallel to the gulf line, starting in the Prior region and ending at the convergence of $\mathrm{ENACW}_{\mathrm{p}}$ and $\mathrm{ENACW}_{\mathrm{t}}$ (subtropical), giving it an arched shape. The Artabro Gulf is the place off the Galicia coast where ENACW, and ENACW are observed and the gulf is the western limit of coastal Cantabrian Sea influence. The upwelling is strongly influenced by the topographic presence of the gulf which generates an 'upwelling shadow' where the rias water exchange is confined near the coast and the $\mathrm{ENACW}_{\mathrm{p}}$ does not penetrate into the rias. The opposite occurs at the southernmost Rias Bajas, where $\mathrm{ENACW}_{\mathrm{t}} \mathrm{upwells}_{\mathrm{s}}$ inside the rias. (C) Elsevier, Paris
\end{abstract}

\section{upwelling / ria / Prior Cape / Artabro Gulf / Cantabrian Sea}

Résumé - Hydrographie du golfe Artabre pendant l'été : limite côtière occidentale de l'eau Cantabrique et upwelling du cap Prior. L'hydrographie du golfe Artabre $\left(1500 \mathrm{~km}^{2}\right)$, situé au nord-ouest de la péninsule Ibérique, a été étudiée dans des conditions météorologiques estivales, pour la première fois, à l'aide de données collectées en août 1993 au cours de la campagne COPLA 893. Pour comprendre cette hydrographie très complexe, il faut considérer trois facteurs : l'upwelling, les deux composantes de l'eau centrale nord-est atlantique (ENACW) et l'échange d'eau avec la ria. Une remontée locale d'eau sub-polaire $\left(\mathrm{ENACW}_{\mathrm{p}}\right)$ est induite par le vent près du cap Prior. Le panache est à l'extérieur du golfe mais reste sur le plateau continental. La zone frontale, riche en nutriments et en chlorophylle, suit la ligne de côte en formant un arc qui s'étend du cap Prior jusqu'à la convergence des eaux sub-polaire (ENACW $_{\mathrm{p}}$ ) et sub-tropicale $\left(\mathrm{ENACW}_{\mathrm{t}}\right)$. Ces deux masses d'eaux se rencontrent dans le golfe Artabre qui constitue la limite côtière occidentale d'influence de la mer Cantabrique. L'upwelling est très marqué par la topographie du golfe qui engendre une " remontée fantôme » où l'échange d'eau avec les rias est confiné près de la côte, empêchant l'ENACW ${ }_{p}$ de pénétrer dans les rias. La situation inverse est observéc plus au sud (rias Bajas) où $\mathrm{l}^{\prime} \mathrm{ENACW}_{\mathrm{t}}$ rcmonte à l'intéricur des rias. C Elscvicr, Paris

\section{upwelling / ria / cap Prior / golfe Artabre / mer Cantabrique}

\footnotetext{
* Correspondence and reprints
} 


\section{INTRODUCTION}

The Galician coast (north-western Iberian Peninsula) is a marine region affected by episodic upwelling events which occur usually between May and September. The main factors that account for eastern North Atlantic central water (ENACW) upwelling are the northern winds [16] and the circulation of ENACW from the Azores Islands or the Bay of Biscay $[10,23]$. Upwelling occurs off the coast of Galicia [11] and is easily detectable due to the cooling of surface water [17]. Subsurface seawater upwelled near the Cape Finisterre area was observed by Fraga et al. [12] as a quasi-permanent upwelling during summer. This area, which is the most influenced by upwelling, is generally the only one considered $[1,11$, 16, 24]. Nevertheless, upwelling is also present in the northernmost area, affecting the area of Prior Cape, east of the Artabro Gulf. Recently, the meso-scale characteristics of upwelling off the Galician coast have been described in accordance with silicon data on sediment and water column [22]. These authors indicated that: (1) Galician upwelling to the north of Cape Finisterre is discontinuous and remains distant from the coast, being near to the edge of the continental shelf and (2) upwelling in the proximity of Prior Cape must also be considered. For this reason, it was necessary to obtain a detailed

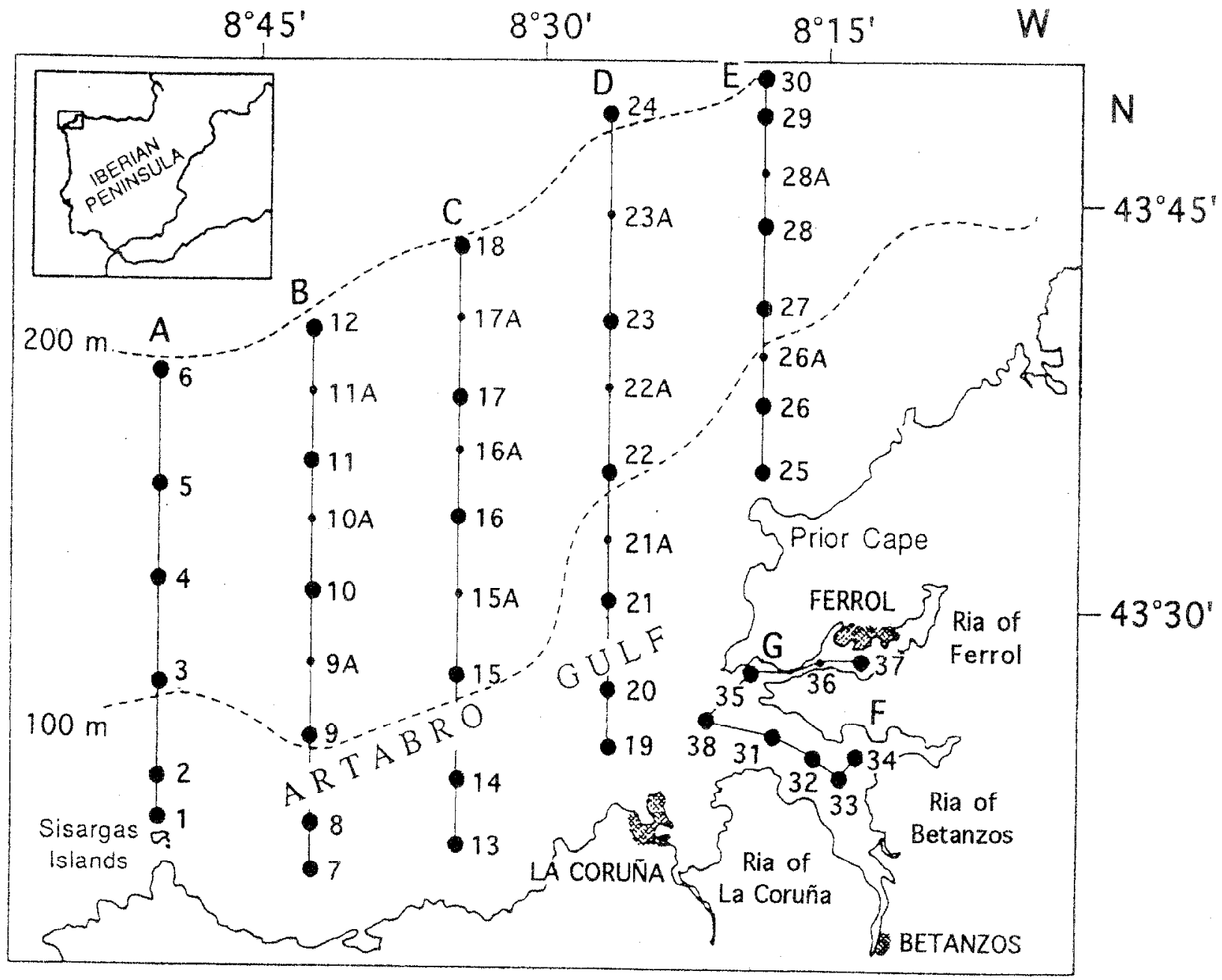

Figure 1. The Artabro Gulf lies in the north-westem coast of the Iberian Peninsula. The gulf is open to the ocean with a surface area of $1500 \mathrm{~km}^{2}$ up to the $200 \mathrm{~m}$ depth isobath. These waters were studied in the first 2 weeks of August 1993, during the 'COPLA 893' research cruise. Seven sections (A-G) with 38 hydrographic stations (large dark points), plus 11 CTD (smill dark points) were sampled. 
description, on a local scale, of upwelling at Prior Cape, which had not been performed to date. This is the main objective of this paper which, for the first time, studies the hydrographic pattern of the Artabro Gulf during summer. To date, only information related to phytoplankton in near-shore waters of the gulf is available $[2,4,7]$ from the monthly monitoring of a permanent station $(80 \mathrm{~m}$ depth off La Coruña), and also there are few studies in the small bay which form the Ria of La Coruña [8] within the Artabro Gulf.

\section{AREA OF STUDY, MATERIAL AND METHODS}

The Artabro Gulf is located in the north-western side of the Galician coast, north of Cape Finisterre and near the far western area of the Cantabrian Sea. It forms a large 46-km long arch open to the ocean and confined by the Sisargas Isles and Prior Cape (figure 1). The $100 \mathrm{~m}$ isobath roughly follows the chord of the arch and the continental slope lies some $24 \mathrm{~km}$ away from the ends and $36 \mathrm{~km}$ from its centre. In the eastern part of the gulf are the two largest Galician rias altas: the Ferrol and Betanzos rias (figure 1). The near Ria of La Coruña, where the river contribution is very low, may be considered as a bay within the gulf [26].

The surveyed area covers the Artabro Gulf arch to the $200 \mathrm{~m}$ deep isobath, with an approximate surface area of $1500 \mathrm{~km}^{2}$. This area was sampled during the COPLA 893 research cruise, in the RV Francisco de Paula Navarro, from 3 to 10 August 1993 [27]. Five sections (A to E, figure 1 ) and a further section inside the rias were carried out. In 49 stations, vertical profiles of salinity and temperature were measurcd using a Sca-Bird 25 CTD. The salinity sensor calibration was verified with seawater samples and an 'Autosal' salinometer. Sigma- $t$ was calculated from the CTD data according to the equation applied in UNESCO [25]. In 38 stations, seawater samples were taken using 'General Oceanic' 5 L- Niskin bottles, with the sequence $0,5,10,20,30,40,50,60,75$, $100,125,150,175$ and $200 \mathrm{~m}$ depth in the coastal zone, and $0,2,4,6,10,15$ and $20 \mathrm{~m}$ depth in the rias. Nitrates were analysed using a Technicon AAII autoanalyser, according to the method by Hansen and Grasshoff [15]. For chlorophyll analysis, $250 \mathrm{~mL}$ of water were passed through Whatman $\mathrm{G} / \mathrm{F}$ glass filters, which were then treated with $90 \%$ acetone for $24 \mathrm{~h}$. Chlorophyll was measured by fluorometry, according to Yentsch and Menzel [28], using a Turner Designs fluorometer.

\section{RESULTS AND DISCUSSION}

The hydrography of the Artabro Gulf performed in summer must be understood in terms of three main factors: the local upwelling off Prior Cape, the influence of ENACW and the rias-water exchange.

\subsection{Prior Cape upwelling}

Upwelling takes place in the far eastern areas of the Artabro Gulf, in the proximity of Prior Cape. This upwelling has not been described to date, and is one of the main characteristics of the hydrography in this area during summer. Its plume, as typical in upwelling areas, is well defined by a surface isotherm map (figure 2). A decrease in water temperature from 19 to $15^{\circ} \mathrm{C}$, i.e. $4{ }^{\circ} \mathrm{C}$ in $18 \mathrm{~km}$ is observed. Minimum temperatures are detected near the cape, continuing westward, parallel to the arch of the gulf. The thermal front is, then, near the coast and does not cross the continental margin, i.e. it is a platform-based upwelling. Both characteristics were predicted by Prego and Bao [22] in terms of the silicate cycle in upwelling off the Galician coast. Upwelling off Finisterre is different; it is more extensive and crosses the continental margin [11] as shown by the satellite image (figure 2) obtained 1 week prior to the COPLA 893 cruise. The isotherm map highlights a further fact: the presence of an 'upwelling shadow area' within the Artabro Gulf. The rias in this area are isolated from the front, and upwelling does not reach them. This is yet another difference between these rias and those south of Finisterre where upwelling not only reaches the coastline $[11,22]$, but also penetrates the rias, accelerating its positive estuarine residual circulation [20]. Consequently, upwelling off Prior Cape and its influence within the Artabro Gulf is strongly affected locally by topographic features of the coastline, as occurs, although to a lesser extent, in the area surrounding Cape Finisterre [1].

The plume of the upwelling at Prior Cape is also very clearly defined if chlorophyll distribution is considered (figure 2). Chlorophyll acts as a tracer due to phytoplanktonic activity in response to upwelling. The line of maximum relative chlorophyll values well concords with the line of minimum relative temperature (figure 2). There are some higher values $\left(5 \mathrm{mg} \cdot \mathrm{m}^{-3} \mathrm{Chl} a\right.$, figure 2$)$ comparable to other areas in Galicia [3,9].

The wind system accounting for upwelling off Prior Cape is the result of the prevailing meteorological conditions in the north of the Atlantic Ocean. Figure 3 shows the posi- 

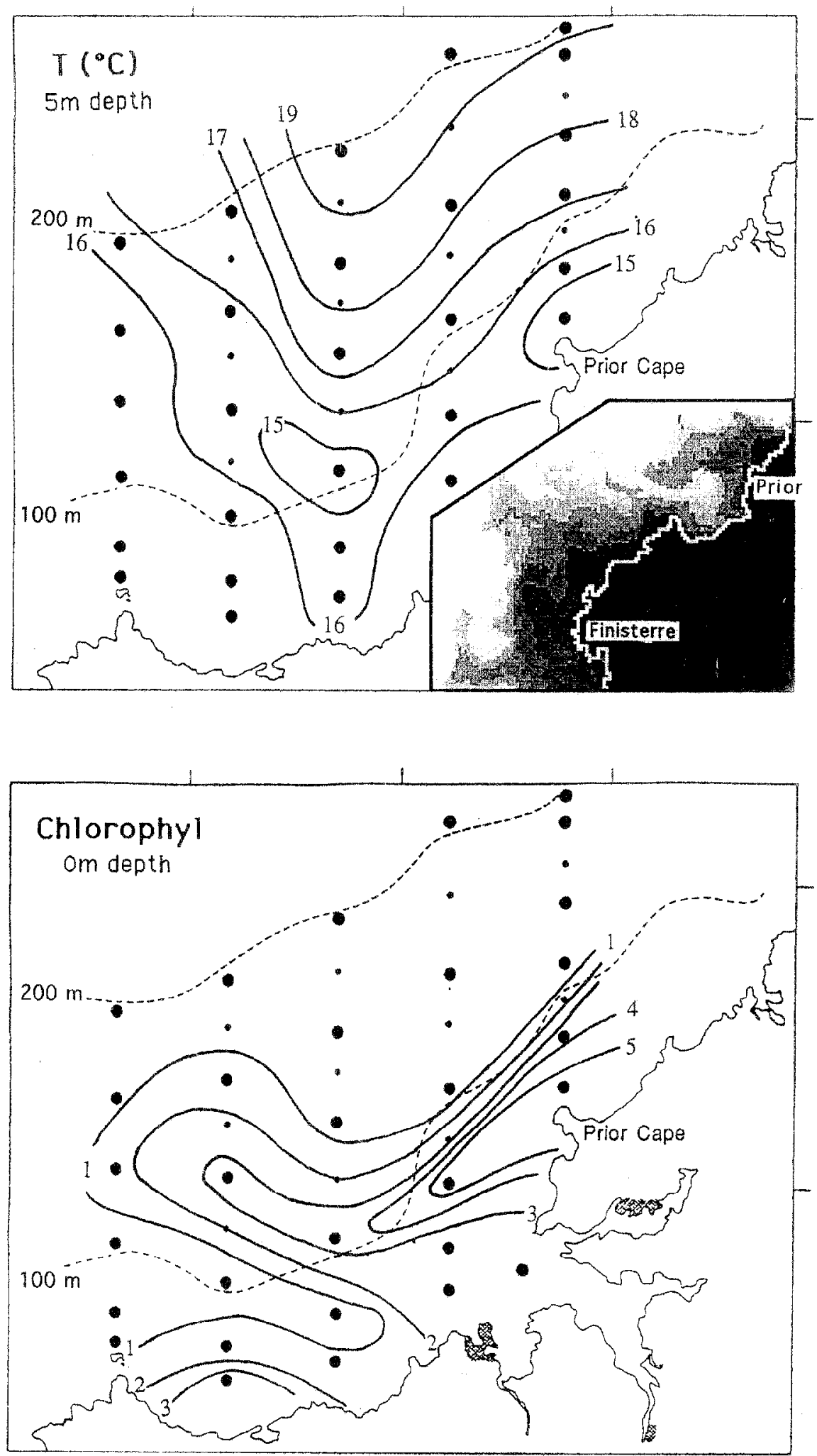

Figure 2. Upwelling frontal zone. Upper map: Surface isotherm $\left({ }^{\circ} \mathrm{C}\right)$ from CTD data in the Artabro Gulf and satellite image (lower right-hand corner) for the Prior Cape and Finisterre upwelling. Lower map: Surface chlorophyll $a\left(\mathrm{mg} \cdot \mathrm{m}^{-3}\right)$ isolines. 


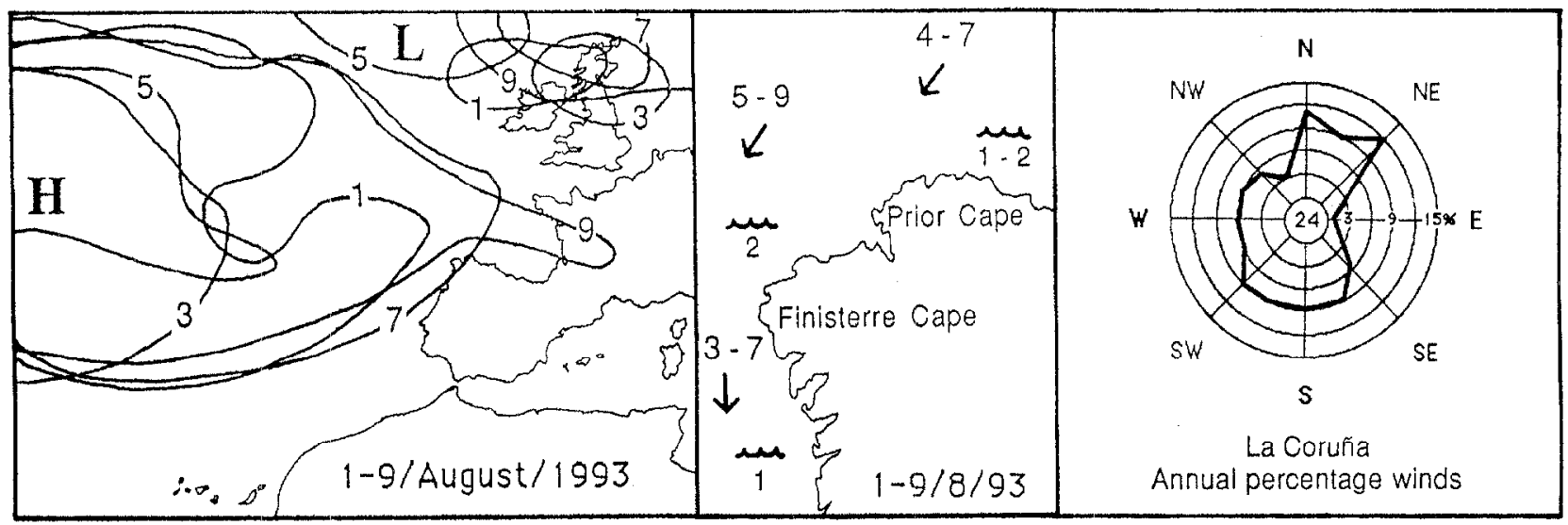

Figure 3. Meteorological conditions (data from the Spanish 'Instituto Nacional de Meteorología'). Left-hand map: low (L) and high (H) surface pressures and isobars ( $1024 \mathrm{mb}$ for $\mathrm{H}$ and $1008 \mathrm{mb}$ for $\mathrm{L}$ ), from 1 to 9 (number in isolines), August 1993. Centre map: wind direction and speed $\left(\mathrm{m} \cdot \mathrm{s}^{-1}\right)$ and wave height $(\mathrm{m})$ in the Galician coast during 'COPLA $893^{\prime}$ cruise. Right: The compass card of annual frequency average of La Coruña. In summer, north and north-east winds are dominant.

tion of the high and low pressure areas in western Europe, both prior to and during the COPLA 893 cruise. Low pressures over the British. Isles maintained their position during the first fortnight of August due to the continuous arrival of storms. Therefore, north-east winds prevailed in the Galician Sea with speeds ranging from 1 to $9 \mathrm{~m} \cdot \mathrm{s}^{-1}$ (figure 3). These winds are the most common in the area in summer (figure 3). Consequently, the wind-induced topographical upwelling described is the first hydrographic pattern of the Artabro Gulf, most commonly occurring in summer, but showing some variations depending on the wind intensity or direction (north or north-east).

\subsection{Area of ENACW influence and frontal zone}

Subsurface water (100-400 m depth) in the north-western zone of the Ibcrian Pcninsula presents a flow pattern as proposed by Fraga et al. [12]. These authors consider that an area of confluence of two water masses is formed off the Galician coast near Cape Finisterre. The water mass off western Galicia is North Atlantic Central Water (NACW), whereas further north, where the NACW is highly modified, is the Biscay Gulf Central Water. Subsequently, Fiuza [10] defined the water that lies south of Finisterre as eastern North Atlantic Central Water (ENAW). Recently, it was redefined by Ríos et al. [23] as $\mathrm{ENAW}_{\mathrm{t}}$, i.e. of subtropical origin, and $\mathrm{ENAW}_{\mathrm{p}}$, i.e. of subpolar origin that lies north of Finisterre. However, ENACW is the most suitable acronym and it is the terminology used here.
Both water masses $\left(\mathrm{ENACW}_{\mathrm{p}}\right.$ and $\left.\mathrm{ENACW}_{\mathrm{t}}\right)$ are found in the Artabro Gulf. At the ends, the temperaturc/salinity diagram (TS) of the stations (figure 4) indicates the presence of $\mathrm{ENACW}_{\mathrm{p}}$ in Section $\mathrm{E}$ (figure 1), whereas in Section. A (figure I) $\mathrm{ENACW}_{\mathrm{t}}$ is present. The water upwelling off Prior Cape, whose front penetrates the Artabro Gulf, is $\mathrm{ENACW}_{\mathrm{p}}$ coming from the Cantabrian

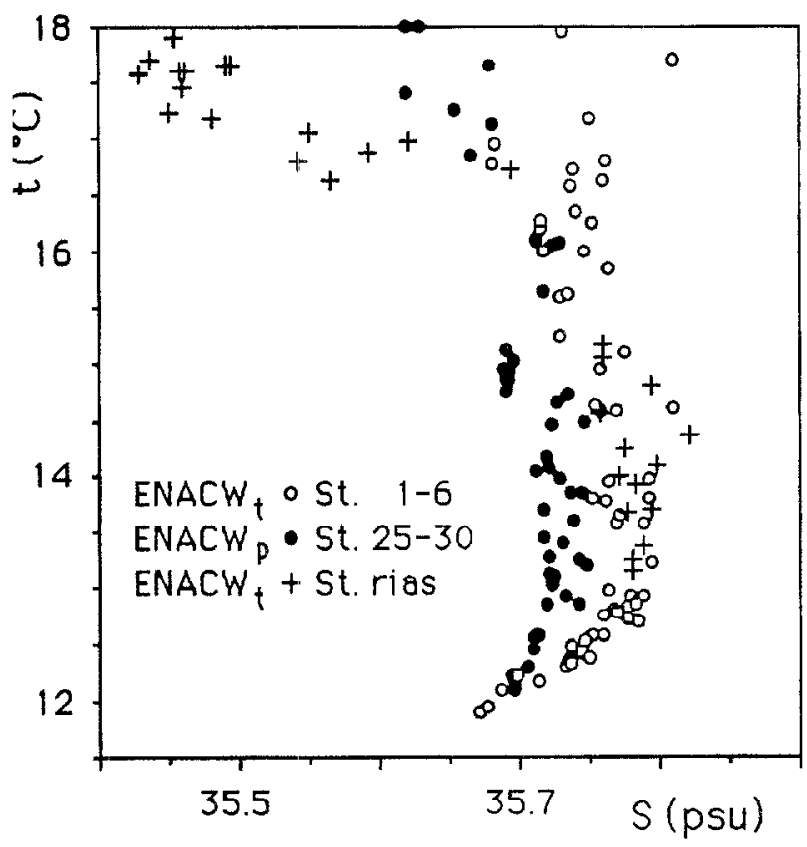

Figure 4. Temperature/salinity diagram to western stations (1 to 6 , Section A, see figure 1), eastern (stations 25 to 30 , Section E) and rias (stations 31 to 38 , Section $\mathrm{G}$ ) in the Artabro Gulf during the 'COPLA 893' cruise. 

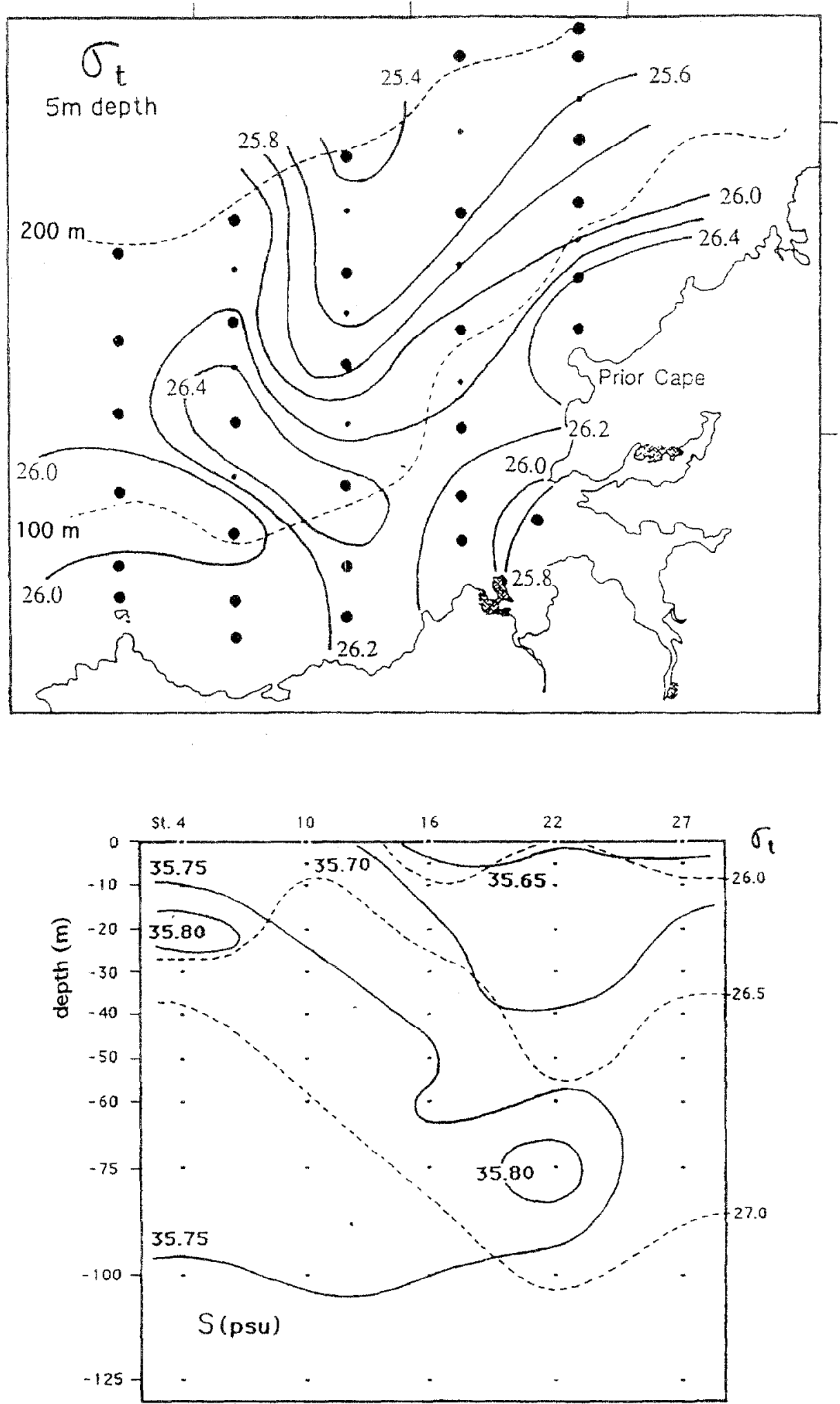

Figure 5. Upper map: Surface isopycnes (sigma- $t$ in $\mathrm{kg} \cdot \mathrm{m}^{-3}$ ) in the Artabro Gulf. Lower map: Vertical isopycnes (sigma- $t$ in $\mathrm{kg} \cdot \mathrm{m}^{-3}$ ) and iso. halines in a section parallel to the gulf coast (stations 4-10-16-22-27, see figure $I$ ). 
Sea. North of the front, this water mass would occupy a subsurface position. Between the front and the Artabro coast there is a water influenced by ENACW, which is also found in the rias, as suggested by their more saline TS (figure 4). Consequently, the water upwelling off Prior Cape is different to that of Finisterre upwelling, showing yet another difference between both phenomena.

The Artabro Gulf would be the place of confluence for both water masses off the coast. In a section parallel to the coast (see lower map, figure 5), water with a higher saline content is observed to the west towards the area where it should be moving due to the arrival of a less dense, saline surface water coming from the Cantabrian Sea (figure 5). During upwelling events, the surface Cantabrian water is transported westwards $[6]$ with the $\mathrm{ENACW}_{\mathrm{p}}$ appearing below it with maximum salinity. Its flow would originate and would maintain the instability of the density present in the area (see lower map, figure 5). It was previously highlighted [14] that there was a penetration of $\mathrm{ENACW}_{\mathrm{p}}(50-100 \mathrm{~m}$ depth), on $\mathrm{ENACW}_{\mathrm{t}}$, beyond the Galician Shelf.

An important fact occurring in the Artabro Gulf, derived from these events, is that the confluence of both ENACWs extends the front to the west of the gulf (station 10, figure 1). At this point, the effect of the Prior Cape coastline on $\mathrm{ENACW}_{\mathrm{p}}$ (Section E, figure 6), is

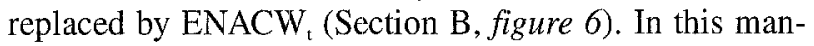
ner, the frontal zone of the Artabro Gulf is arch-shaped and may be considered as the sum of the two phenomena generated by the wind, one more intense due to Prior Cape, and the other produced by the confluence of the two ENACW. Where both coincide, there is a minimum temperature (station 15, figure 2), and subsurface maxima of chlorophyll appear [27].

Consequently, a second hydrographic pattern in the Artabro Gulf would be the presence of two different ENACW. Within the gulf, their relative influence of these water masses may vary depending on the intensity of upwelling occurring in the Finisterre and Prior Cape areas. Although reference is normally made to Finisterre as being the centre of upwelling phenomena, this actually occurs further north, between Finisterre and the Sisargas Isles. Therefore, the eastern edge of Finisterre upwelling should affect the Artabro Gulf. This would be the northerly coastal limit of this upwelling which has, to date, not been documented in detail. The presence of ENACW and surface waters from the Cantabrian Sea mean that this gulf is also the western coastal limit of Cantabrian
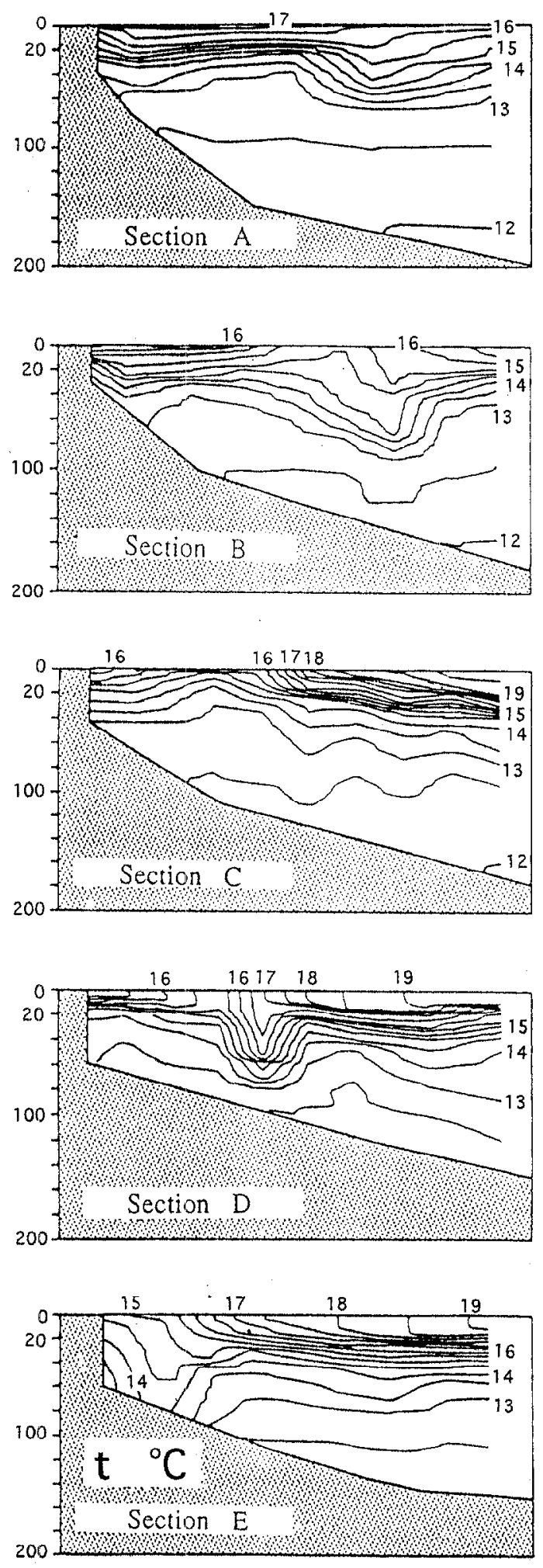

Figure 6. Vertical maps of water isotherms $\left({ }^{\circ} \mathrm{C}\right)$ in the Artabro Gulf (Sections A to $\mathrm{E}$, see figure I). 

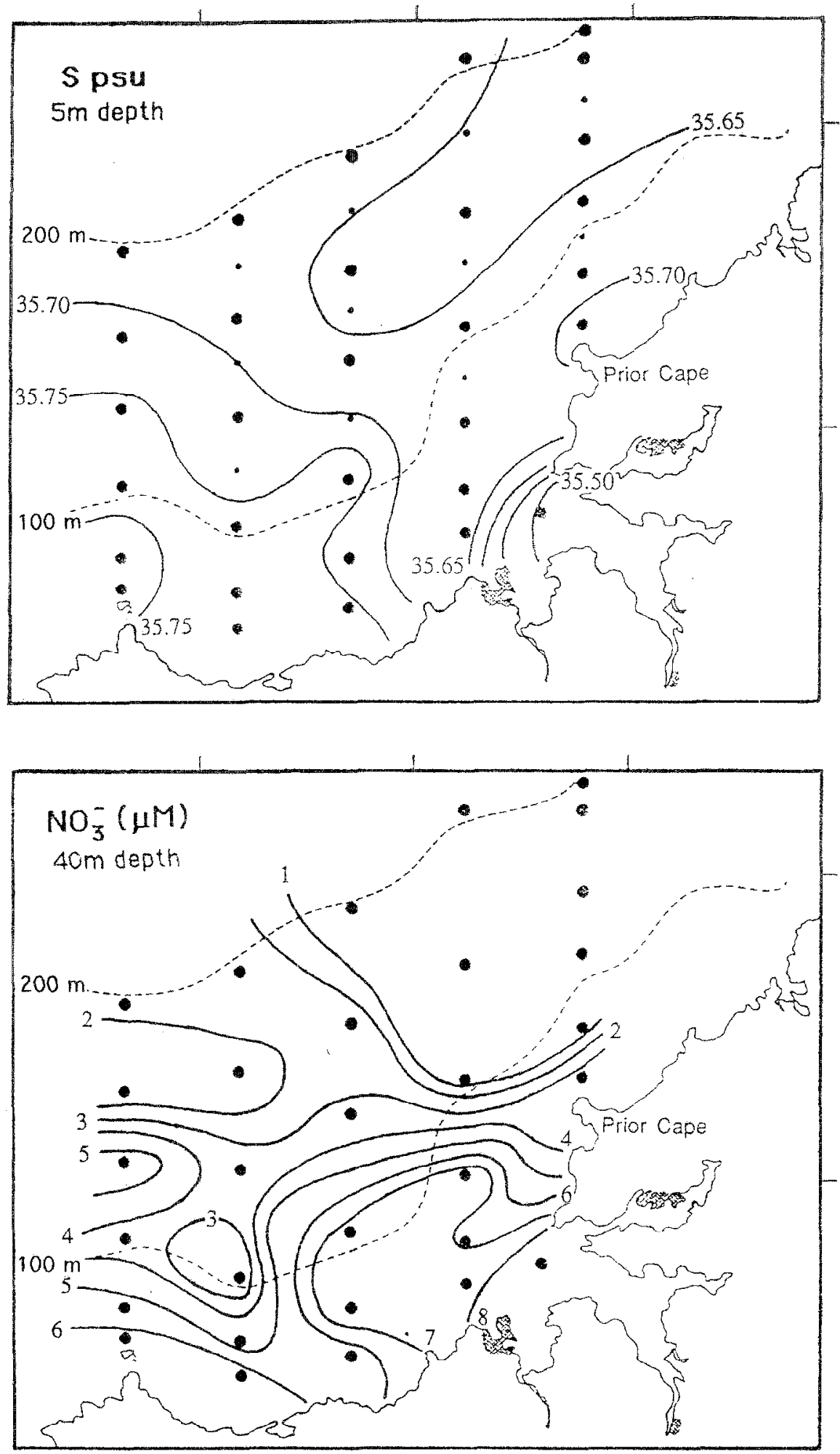

Figure 7. Upper map: Surface isohalines in the Artabro Gulf. Lower map: Subsurface (40 $\mathrm{m}$ depth) isolines of nitrate concentration ( $\mu \mathrm{M}$ ). 


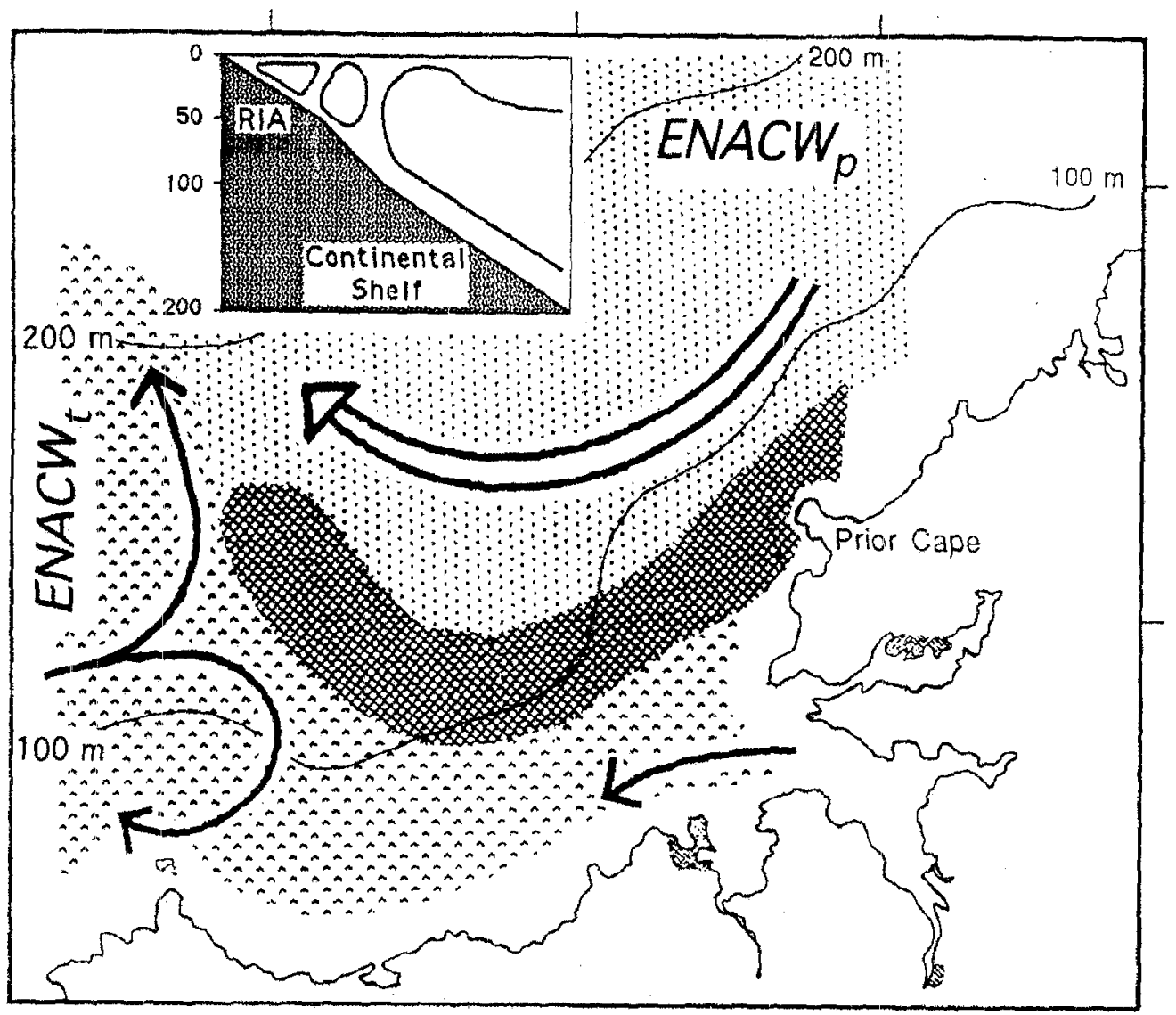

Figure 8. Scheme of summer situation in the Artabro Gulf. Frontal zone (dark reticule), areas of influence of $\mathrm{ENACW}_{\mathrm{t}}\left({ }^{\wedge}\right)$ and $\mathrm{ENACW}_{\mathrm{p}}(\bullet)$ and water circulation (arrows) from rias, Finisterre upwelling and the Cantabrian Sea.

waters throughout the year since, in winter, the polar current flows northward, reaching the Cantabrian coast from Portugal $[5,13]$.

\subsection{Water exchange in the rias and the upwelling shadow zone}

Upwelling off Prior Cape has a secondary hydrographical effect due to the existence of the Artabro Gulf. The eastern coastal water of the Artabro Gulf remains practically isolated, thus generating an 'upwelling shadow zone' affecting the rias of Ferrol, Betanzos and La Coruña (Artabro rias). This would comprise a third hydrographic pattern of the Artabro Gulf. Their rias are distant from the front and the water circulation does not introduce upwelled $\mathrm{ENACW}_{\mathrm{p}}$ inside the Artabro rias. This is contrary to the case of the Rias Bajas, lying south of Finisterre, which receive $\mathrm{ENACW}_{\mathrm{t}}$ during upwelling events [20].
The water present in the subsurface layer in the $\Lambda$ rtabro rias is more saline than the upwelled seawater and, as shown in the TS diagram (figure 4), this would be affected by the influence of $\mathrm{ENACW}_{\mathrm{t}}$. The surface water (upper left hand conner of the TS in figure 4) at the mouth of these rias has a lower salinity due to the river contribution. This fact highlights its influence on the adjacent coastal zone where a less saline, warmer water exists (figure 7 and Section D in figure 6). This water is held against the coast due to the upwelling effect. Since this is less dense, however, it tends to lie on the upwelling water, breaking the continuity of isopycnes of 26.4 (figure 5). In a similar zone off the Rias Bajas, a maximum remineralisation is formed [19] due to the exportation of particulate organic matter (POM), marked by a subsurface maximum of nitrate $(12 \mu \mathrm{M}$, according to [21]). In the case of the Artabro rias, there appear to be two subsurface maximum of nitrate, one near the mouth of the rias $(8 \mu \mathrm{M}$, station 38 , figure 7$)$ with POM originating in 
them, and another $(>7 \mu \mathrm{M}$, stations 15 and 21 , figure 7$)$ with POM falling from the upwelling area. These nitrate concentrations could not be due to upwelling since there is only $4 \mu \mathrm{M}$ in Prior Cape (figure 7). Both maxima would mark the upwelling limits and the influence of the rias.

The 'shadow upwclling zonc' described carlicr has important consequences in the fertilisation of the Artabro rias. It contributes to clarify why the fertilisation process is greater in the case of the Rias Bajas [21] than in the rias of the Artabro Gulf. The different level of fertilisation in both sets of rias would also be related to the differing presence of red tides in the rias. The first two steps in the formation of a red tide in any ria (high production due to upwelling and high remineralisation; [81) are avoided due to the presence of the shadow upwelling zone. Therefore, it seems possible to justify the far lower incidence of red tides in the Artabro rias relative to the Rias Bajas.

\subsection{Circulation scheme}

The main hydrographic pattern in the Artabro Gulf could be summarised as follows: 1) the frontal zone, 2) the $\mathrm{ENACW}$ influence areas and 3) the isolated rias water.

The vertical profiles of isotherms in the five sections provide complementary information (figure 6) and give a good overview of dynamic hydrography in the gulf. Section E corresponds to Prior Cape where the water upwells. A similar situation is observed in Section D where a temperate outgoing water from the rias appears. This water should divert westward due to the presence of the front and must be the cause of downwelling shown by the fall in the isotherms prior to upwelling. Neither does water enter subsuperficially into the rias since isotherm $13{ }^{\circ} \mathrm{C}$ remains horizontal, reaching the bottom before the mouth of the rias. This fact, along with the presence of the two maximum remineralisations mentioned earlier, suggests the existence of a double cell flow, apart from the upwclling ccll (figure 8).

Further details can be deduced from Section B (figure 6) where the $13^{\circ} \mathrm{C}$ isotherm is not horizontal, pointing to the retention of coastal water and the confluence of the two ENACW. Station 9 presents a minimum of nitrate $(2 \mu \mathrm{M})$ and chlorophyll (figures 2,7$)$. All this, along with the data on salinity, temperature and density (figures 2 , 5,7 ), suggests the existence of a clockwise-moving eddy that concentrates poor surface water.
The final result is the overall diagram in figure 8 which, in agreement with the meteorological conditions, must be a typical situation in the north Galicia coast during summer upwelling events.

\section{CONCLUSIONS}

The Artabro Gulf zone is a complex hydrographical area during summer upwelling events since 1) it is under the influences of two different ENACW, 2) Prior Cape upwelling occurs and 3) water exchange processes between the $\Lambda$ rtabro rias Ferrol, Bctanzos and La Coruña and the adjacent coastal platform.

A local wind-induced upwelling occurs in the proximity

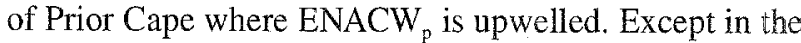
cape neighbourhood, the frontal zone lies off the gulf coastline but inside the continental shelf. The upwelling area is strongly influenced by the topographic presence of the Artabro Gulf, so these rias remain isolated from upwelling as opposed to what occurs south of Cape Finisterre where the upwelled $\mathrm{ENACW}$, penetrates into the rias.

The Artabro Gulf is the place of confluence for $\mathrm{ENACW}_{\mathrm{t}}$ and $\mathrm{ENACW}_{\mathrm{p}}$ water masses. The Cantabrian surface water and $\mathrm{ENACW}_{\mathrm{p}}$ in the gulf are the western limit of coastal Cantabrian Sea influence. The ENACW sence in the gulf is the result of Finisterre upwelling. Artabro coastal water is confined near the coast, and the confluence of the two ENACWs extends the frontal zone of Prior Cape, giving it an arched shape.

\section{Acknowledgements}

The authors are grateful to the kind cooperation of the scientists on the COPLA 893 cruise and the crew of the RV Francisco de Paula Navarro, the Spanish 'Instituto Nacional de Meteorología' and the 'Departamento de Electrónica e Computación' at the University of Santiago for the meteorological and satellite information. They also wish to thank María Angeles García for her kind assistance. This paper is a contribution to the IEO Spanish Project 'Seguimiento de la contaminación del Aegean Sea' financed by the 'Ministerio de Medio Ambiente', 'Series Históricas' (ref. 1007) and to E.U. 'OMEX' Project (ref. MAS2-CT93-0069). 
[1] Blanton J.O., Atkinson L.P., Fernandez de Castillejo F., Lavín A., Coastal upwelling off the Rias Bajas, Galicia, Northwest Spain I: hydrographic studies, Rapports et Procès Verbaux des Réunions CIEM, 183 (1984) 79-90.

[2] Bode A., Varela M., Planktonic carbon and nitrogen budgets for the N-NW Spanish shelf: the role of pelagic nutrient regeneration during upwelling events, Sci. Mar. 58 (1994) 221-231.

[3] Bode A., Casas B., Fernandez E., Marañon E., Serret P., Varela M., Variability of phytoplankton biomass and primary productivity in the shelf waters of the upwelling area of N-NW Spain, I.C.E.S., C.M. 1993/L:53 (1993).

[4] Bode A., Casas B., Varela M., Size-fractionated primary productivity and biomass in the Galician shelf (NW Spain): netplankton versus nanoplankton dominance, Sci. Mar. 58 (1994) 131-141.

[5] Botas J.A., Bode A., Fernández E., Anadón R., Description of an intrusion of high salinity water in the Cantabrian sea: distribution of inorganic nutrients related to phytoplankton composition, Inv. Pesq. 52 (1988) 561-574.

[6] Botas J.A., Fernandez E., Bode A., Anadón R., A persistent upwelling off the central cantabrian coast (Bay of Viscay), Estuar. Coast. Shelf S. 30 (1990) 185-199.

[7] Casas B., Varela M., Canle M., González N., Bode A., Seasonal variations of nutrients, seston and phytoplankton, and upwelling intensity off La Coruña (NW Spain), Estuar. Coast. Shelf S. 44 (1997) 767-778.

[8] Cosme A., Prego R., Caraterísticas generales de la Ría de La Coruña y su cuenca fluvial, Series Quím. Ocean. 2 (1995) $25-47$.

[9] Estrada M., Phytoplankton distribution and composition off the coast of Galicia (Northwest of Spain), J. Plankton Res. 6 (1984) 417-434.

[10] Fiuza A.F.G., Hidrologia e dinamica das aguas costeiras de Portugal, thesis, University of Lisbon, Portugal, 1984, 294 p.

[11] Fraga F., Upwelling off the Galician coast, Northwest Spain, in: Richards F.A. (Ed.), Coastal Upwelling, American Geophysical Union, 1981, pp. 176-182.

[12] Fraga F., Mouriño C., Manriquez M., Las masas de agua en la costa de Galicia: junio-octubre, Resultados Expediciones Científicas B/O Cornide, 10 (1982) 51-77.

[13] Frouin R., Fiuza A.F.G., Ambar I., Boyd T.J., Observations of a poleward surface current off the coasts of Portugal and Spain during water, J. Geophys. Res. 95 (1990) 679-691.

[14] Fruchaud-Laparra B., Phygas 32. Etude hydrologique et variations saisonnières dans le proche Atlantique en 1973, Rapp. Scicnt. Techn. CNEXO n 26 (1976) 39-54.
[15] Hansen H.P., Grasshoff K., Automated chemical analysis, in: Grasshoff K., Ehrhardt M., Kremlin K. (Ed.), Methods of Seawater Audysis, Verlag Chemie, 1983, pp. 368-376.

[16] McClain C.R., Chao S., Atkinson L.P., Blanton J.O., de Castillejo F., Wind driven upwelling in the vicinity of Cape Finisterre, Spain, J. Geophys. Res. 91 (1986) 8470-8486.

[17] Molina R., Contribución al estudio del "upwelling" frente a la costa noroccidental de la peninsula ibérica, Bol. IEO 152 (1972) 3-39.

[18] Prego R., Flows and budgets of nutrient salts and organic carbon in relation to a red tide in the ria of Vigo (NW Spain), Mar. Ecol. Prog. Series 79 (1992) 289302.

[19] Prego R., Nitrogen interchanges generated by biogeochemical processes in a Galician ria, Mar. Chem. 45 (1994) 167-176.

[20] Prego R., Fraga F., A simple model to calculate the residual flows in a Spanish ria. Hydrographic consequences in the ria of Vigo, Estuar. Coast. Shelf S. 34 (1992) 603-615.

[21] Prego R., Belzunce M.J., Varela M., Fertilization of the Galician coastal area. OMEX, Second Annual Report (June 1995) (1995) D-105-113.

[22] Prego R., Bao R., Upwelling influence on the Galician coastal: silicate in shelf water and under lying surface sediments, Cont. Shelf Res. 17 (1997) 307-318.

[23] Ríos A.F., Pérez F.F., Fraga F., Water masses in upper and middle North Atlantic Ocean east of Azores, Deep-Sea Res. 39 (1992) 645-658.

[24] Tenore K.R., Alvarez-Ossorio M., Atkinson L.P., Cabanas J.M., Cal R.M., Campos H.J., Castillejo F., Chesney E.J., Gónzalez N., Hanson R.B., McClain C.R., Miranda A., Novall M., Román M.R., Sánchez J., Santiago G., Valdés L., Varela M., Yoder J., Fisheries and oceanography off Galicia, NW of Spain (FOG): mesoscale spatial and temporal changes in physical processes and resultant patterns of biological productivity, Progr. Oceanogr. 47 (1982) 701-772.

[25] UNESCO Tenth report of the joint pancl on occanographic tables and standard, UNESCO Techn. Pap. Mar. Sci. n ${ }^{\circ} 36$ (1981) 40 p.

[26] Varela M., Prego R., Canle M., Lorenzo J., The Ria de La Coruña, is hidrollogically a ria? Rev. Geocien. GAIA 9 (1994) 3-5.

[27] Varela M., Bode A., Alvarez M.T., Prego R., Canle M., Casas B., Lorenzo J., Mariño D., González I., Carballo R., Vilas M., I. Sistema Pelágico, in: Seguimiento de la contaminación producida por el accidente del buque Aegean Sea, Servicio de Publicaciones del Ministerio de Obras Públicas y Transportes, 1996 (in press).

[28] Yentsch C.S., Menzel D.W., A method for the determination of phytoplankton chlorophyll and phaeophytin by fluorescence, Deep-Sea Res. 10 (1963) 221-231. 